УДК $81 ’ 373.7: 81 ' 253=161.2+811.111$

DOI https://doi.org/10.26661/2414-1135-2021-84-27

\title{
ОСОБЛИВОСТІ ПЕРЕКЛАДУ ФРАЗЕОЛОГІЧНИХ ОДИНИЦЬ ЕКОНОМІЧНОЇ ГАЛУЗІ
}

\author{
Петрина О. С. \\ кандидат філологічних наук, доцент, \\ дочент кафедри англійської філологіі \\ Прикарпатський національний університет імені Василя Стефаника \\ вул. Шевченка, 57, Івано-Франківськ, Украӥна \\ orcid.org/0000-0001-5311-6777 \\ petrynaoxana@meta.ua \\ Цюцюра Д. Р. \\ магістр кафедри англійської філології \\ Прикарпатський національний університет імені Василя Стефаника \\ вул. Шевченка, 57, Івано-Франківськ, Украӥна \\ orcid.org/0000-0002-4534-5788 \\ dianatsiutsiura@gmail.com
}

\begin{abstract}
Ключові слова: фразеологізм, способи перекладу, описовий переклад, дослівний переклад, фразеологічний аналог, фразеологічний еквівалент.
\end{abstract}

Статтю присвячено дослідженню способів перекладу фразеологічних одиниць англійської економічної термінології українською мовою. У статті представлено основні труднощі, які виникають під час перекладу фразеологізмів з англійської українською мовою. Окреслено чинники, від яких залежать правильність і точність перекладу фразеологічних одиниць, серед яких перше місце посідає джерело походження фразеологізму (однакове чи відмінне) у мові оригіналу та в мові перекладу. У роботі розглянуто способи перекладу фразеологічних одиниць загалом і бізнес-фразеологізмів зокрема. Основні способи перекладу фразеологічних одиниць поділяють на фразеологічні (переклад за допомогою фразеологічного аналога та переклад за допомогою абсолютного/відносного еквівалента) та нефразеологічні (описовий переклад, дослівний переклад та контекстуальна заміна). Встановлено, що переклад фразеологічних одиниць економічної сфери діяльності здійснюється за допомогою описового способу, фразеологічного аналога, фразеологічного еквівалента, дослівно, а також за допомогою транслітерації з поясненням. Здійснено аналіз зазначених способів перекладу, описано переваги і недоліки кожного з них. 3'ясовано, що для передачі фразеологічних одиниць економічної сфери діяльності найефективнішим та найрегулярнішим способом перекладу є описовий. Використання описового способу перекладу надає можливість точно та змістовно передати значення термінологічного фразеологізму. Найсуттєвішими недоліками зазначеного способу перекладу $\epsilon$ його громіздкість та здатність позбавити фразеологічну одиницю образності. Переклад за допомогою фразеологічного аналога та дослівний переклад належать до менш регулярних способів перекладу термінологічних фразеологізмів. Особливість дослівного способу перекладу полягає в його додатковому поясненні, яке часом може бути надто громіздким та позбавляти фразеологічну одиницю лаконічності, проте воно сприяє правильному розумінню фразеологічної одиниці. Визначено, що переклад за допомогою фразеологічного еквівалента та транслітерація з додатковим поясненням для передачі фразеологічних одиниць економічної сфери діяльності українською мовою використовуються вкрай рідко. 


\title{
TRANSLATION PECULIARITIES OF PHRASEOLOGICAL UNITS OF ECONOMIC FIELD
}

\author{
Petryna O. S. \\ Ph. D., Associate Professor, \\ Associate Professor at the Department of English Philology \\ Vasyl Stefanyk Precarpathian National University \\ Shevchenko str., 57, Ivano-Frankivsk, Ukraine \\ orcid.org/0000-0001-5311-6777 \\ petrynaoxana@meta.ua \\ Tsiutsiura D. R. \\ Master Student at the Department of English Philology \\ Vasyl Stefanyk Precarpathian National University \\ Shevchenko str., 57, Ivano-Frankivsk, Ukraine \\ orcid.org/0000-0002-4534-5788 \\ dianatsiutsiura@gmail.com
}

Key words: idiomatic

expressions, ways of translation, descriptive translation, word for word translation, phraseological analogue, phraseological equivalent.
The article is devoted to the study of ways of translation of phraseological units of English economic idiomatic expressions into Ukrainian. The article presents the main difficulties of translation of idiomatic expressions from English into Ukrainian and explains their basic reasons. The factors that determine the correctness and accuracy of the translation of phraseological units have been outlined. Special attention has been paid to the ways of translation of both phraseological units in literary language and economic idiomatic expressions. It has been established that the translation of economic phraseological units is carried out by means of descriptive method, phraseological analogue, phraseological equivalent, word for word translation, transliteration with an explanation and the advantages and disadvantages of each method of translation have been revealed. As it has been determined the most effective and productive way of translation of phraseological units of economic sphere is descriptive translation. The use of descriptive translation makes it possible to convey the meaning of terminological idiomatic expressions accurately and substantively. The major drawbacks of this way of translation are its complexity and its disability to render imagery peculiarities of translated phraseological unit. The translation by means of phraseological analogue and word for word translation belong to less relevant ways of translation of terminological idiomatic expressions. The peculiarity of the word for word translation is an additional explanation. It has been determined that translation with the help of phraseological equivalent and transliteration with additional explanation for the translation of the phraseological units of economics are not so productive.
Постановка проблеми. Невпинний розвиток міжнародних ділових і наукових зв'язків розширює межі економічної термінології та поповнює їі словниковий склад новими термінологічними одиницями, до складу яких входять і фразеологізми. Фразеологічні одиниці становлять унікальний прошарок англійської мови, відображають історію народу, звичаї та традиції, а також менталітет носіїв мови. Невідповідність цілісного значення фразеологізму сумарному значенню компонентів, які входять до його складу, зумовлює складність його перекладу іншою мовою. Проблеми семантики фразеології лягли в основу праць таких учених: М.П. Кочергана, В.С. Ващенка, Л. Вайсгербер, Г.А. Уфімцевої, М.І. Личук, В.Д. Шинкарук, С. Влахова, С. Флорина й інших. Учені зосереджували увагу на формулюванні принципів перекладу фразеологізмів, зважаючи на їхню семантику, походження, а також структурні особливості. Проблеми перекладу англійських фразеологічних одиниць українською мовою також вивчали такі вчені, як: Л.С. Бархударов, 
М. Бейкер, В.Н. Комісаров, Р.П. Зорівчак, І.В. Корунець. Мовознавці детально розглядати труднощі, які виникають під час перекладу, виділяли й аналізували чинники, від яких залежить правильність та точність перекладу, а також грунтовно описували способи перекладу фразеологізмів. Дослідженню бізнес-фразеології присвятили свої праці такі лінгвісти, як: А.В. Доля, Н.М. Пільгуй та інші. Ключове завдання проведених досліджень полягало у формуванні основних способів перекладу фразеологічних одиниць, беручи до уваги водночас їхнє походження, структурні та семантичні особливості. Аналіз наукової літератури засвідчує, що, незважаючи на велику кількість наукових праць, які присвячені дослідженням перекладацьких аспектів фразеології, способам перекладу фразеологічних одиниць галузевих термінологій, саме економічній сфері діяльності належна увага не приділялася.

Мета і завдання статті. Мета наукового дослідження полягає в комплексному аналізі й описі способів перекладу фразеологічних одиниць англійської економічної термінології українською мовою. Реалізація поставленої мети передбачає розв'язання низки таких завдань: розглянути способи перекладу фразеологічних одиниць 3 англійської мови українською, визначити їхні переваги і недоліки; виділити найпродуктивніші способи перекладу фразеологічних одиниць економічної термінології з англійської мови українською.

Предмет і об'єкт дослідження. Об'єктом наукової розвідки є сучасні англомовні й українські фразеологічні одиниці економічної сфери діяльності, а предмет дослідження полягає у вивченні способів перекладу фразеологічних одиниць 3 англійської мови українською.

Виклад основного матеріалу дослідження. Термінологію економічної галузі вирізняє широта тематичного охоплення, оскільки вона проникла і стала невід'ємною складовою частиною майже всіх сфер людської діяльності. Відповідно економічна терміносистема налічує значну кількість фразеологічних одиниць, які здебільшого пов'язані з людиною та різноманітними видами іiі активності. Незважаючи на походження та сферу вживання, фразеологізми належать до тих мовних одиниць, які створюють значні труднощі під час перекладу. Лінгвіст М. Бейкер виділяє чотири типи труднощів, які виникають під час перекладу фразеологізмів. По-перше, це відсутність еквівалента в мові, якою потрібно перекласти фразеологізм. По-друге, контексти, у яких уживаються фразеологізми (тобто контекст цільової та вихідної мови), можуть відрізнятися, що впливає на розкриття змісту фразеологічної одиниці під час перекладу. Навіть якщо в мові, якою потрібно перекласти фразеологізм, уже $є$ аналогічний фра- зеологізм, немає жодних гарантій, що дана фразеологічна одиниця вживається в такому ж контексті, як і фразеологізм у мові, з якої його потрібно перекласти. Тому сумарне значення даних фразеологізмів відрізняється, їхнє трансформування стає неможливим. По-третє, фразеологізм, який потрібно перекласти, може вживатися в різних значеннях, як у буквальному, так і в ідіоматичному. Важливим є те, щоб форма та сенс фразеологічної одиниці в цільовій та вихідній мовах збігалися. По-четверте, сутність фразеологізмів, контекст, у якому вони функціонують, та частота їх уживання в мові, з якої перекладають, i в мові, якою перекладають, можуть відрізнятися $[1$, c. 71$]$. I.В. Корунець визначає чинники, від яких залежать точність та правильність перекладу фразеологічних одиниць [2, с. 187-188]:

1) джерело походження фразеологізму в мові оригіналу й у мові перекладу (те саме чи різниться);

2) кількість образів, які фразеологічна одиниця має в мові перекладу (один, більше, ніж один, декілька образів загалом);

3) сприйняття наявних образів фразеологізму в мові перекладу (чи розуміють носії мови той образ, який закладений в основу фразеологізму);

4) структурна форма фразеологізму (чи можна перекласти фразеологізм без внення ніяких змін у його структуру);

5) наявність повного еквівалента (чи існує в мові перекладу фразеологізм, який би передавав точно такий же або дуже схожий сенс, який передає фразеологізм у мові оригіналу) [2, с. 187-188]. Однак В.Н. Комісаров уважає, що, незважаючи на той факт, що переклад має на меті повноцінну та точну заміну оригіналу, його абсолютно повна тотожність оригіналу є практично недосяжною, тому можна говорити тільки про деяку міру близькості перекладу до оригіналу $[3$, с. 8].

С. Влахов та С. Флорин виділяють два основні шляхи перекладу фразеологізмів - фразеологічний та нефразеологічний $[4$, с. 180]. До фразеологічних способів перекладу, на думку вчених, належить переклад за допомогою еквівалента та переклад за допомогою фразеологічного аналога, тоді як серед нефразеологічних способів перекладу були зазначені такі, як описовий переклад, дослівний переклад (калькування) та контекстуальна заміна [4, с. 181].

Отже, вибір адекватного способу перекладу окремого фразеологізму насамперед залежить від образності даного фразеологізму, складності, особливості його семантичної структури, унікальності його значення. М.I. Личук і В.Д. Шинкарук визначили основні способи перекладу фразеологічних одиниць: переклад за допомогою еквівалента (повного та часткового), переклад за допомогою 
фразеологічного аналога, дослівний переклад, або калькування, описовий переклад та контекстуальна заміна $[5$, с. 5$]$.

Оскільки фразеологічні одиниці фахової лексики належать до галузевих термінологій і вирізняються точністю й однозначністю, то і вимагають особливого підходу до визначення способів їх перекладу. А.В. Доля та Н.М. Пільгуй визначили основні способи перекладу бізнес-ідіом [6, с. 65]:

1) переклад за допомогою абсолютного еквівалента;

2) переклад за допомогою відносного еквівалента;

3) переклад за допомогою фразеологічного аналога;

4) описовий переклад [6, с. 65].

Дослідники вважають, що переклад за допомогою відносного еквівалента $\epsilon$ найпоширенішим способом перекладу бізнес-ідіом. Тоді як переклад за допомогою фразеологічного аналога посідає друге місце. Найменш поширеними є такі способи перекладу, як переклад за допомогою абсолютного еквівалента й описовий переклад. У разі перекладу за допомогою відносного еквівалента не змінюється суть фразеологізму, саме тому перекладачі найчастіше послуговуються даним способом перекладу. Тоді як у разі перекладу за допомогою абсолютного еквівалента чи фразеологічного аналога завдання перекладача знайти в мові перекладу такий фразеологізм, який би чітко передавав той, який ужитий в мові оригіналу. В описовому перекладі зазвичай втрачається образність самої фразеологічної одиниці [6, с. 65].

3 огляду на особливості фразеологічних одиниць та труднощі їх перекладу, а також беручи до уваги дослідження в галузі лінгвістики та перекладу, виділяємо такі способи перекладу фразеологізмів економічної галузі:

1) переклад за допомогою еквівалента;

2) переклад за допомогою фразеологічного аналога;

3) дослівний переклад / калькування;

4) описовий переклад;

5) переклад за допомогою транслітерації 3 додатковим поясненням.

Обсяг матеріалу для проведення дослідження 337 фразеологічних одиниць економічної семантики англійської мови та така ж кількість їх українських відповідників, дібраних методом суцільної вибірки з економічних тлумачних словників англійської й української мов, а також двомовних словників. Зазначимо, що фразеологічними одиницями економічного спрямування вважаємо ті, які зафіксовані в економічних та бізнес-словниках вітчизняного та/чи іноземного видання. Отже, усі фразеологічні одиниці, подані як приклади, підкріплені відповідним посиланням, що засвідчує їхню приналежність до даної термінології.

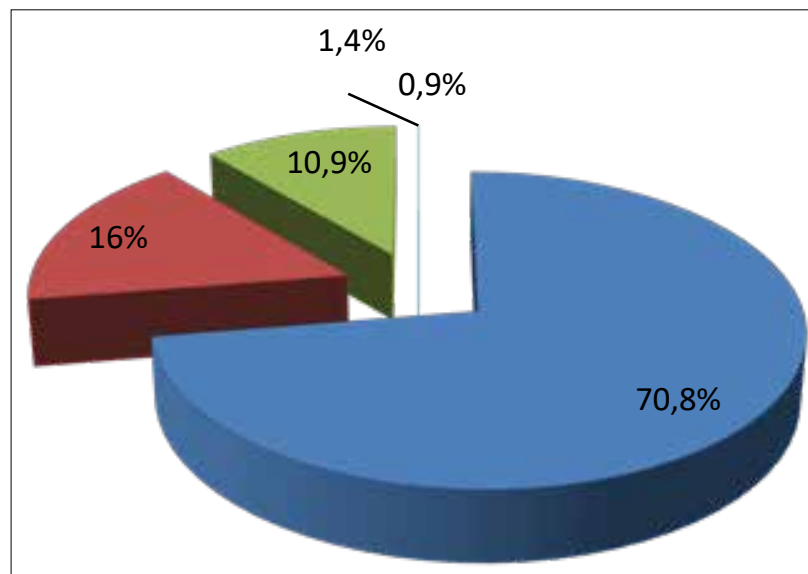

口 Описовий переклад

Переклад за допомогою фразеологічного аналога

$\square$ Дослівний переклад(калькування)

- Переклад за допомогою еквівалента

$\square$ Транслітерація з додатковим поясненням

\section{Рис. 1. Способи перекладу фразеологічних одиниць економічної термінології 3 англійської мови українською мовою}

Результати дослідження засвідчують, що найпоширенішим способом перекладу фразеологічних одиниць економічної термінології $є$ описовий переклад. Даний спосіб перекладу також називають перифразом, уточненням, поширенням, конкретизацією, експлікацією. За допомогою описового перекладу було перекладено 238 фразеологічних одиниць, що становить $70,8 \%$ фразеологізмів від загальної кількості вибірки. У разі перекладу фразеологічних одиниць термінологічного характеру описовий переклад - це фактично тлумачення значення певного фразеологізму, наприклад: golden handshake - значна грошова компенсачія, що виплачується адміністратору високого рангу в разі його звільнення [7]; golden handcuffs - значна винагорода провідному співробітнику фірми, компанії, щзо видається з метою утримання цьього керівника від переходу на роботу в іншу фірму [7]; goldilocks economy - тимчасовий стан економіки в деяких країнах, що характеризуються стійкими темпами росту та низьким рівнем інфляиії [8]; green audit - перевірка впливу діяльності компанії на навколишне середовище [8]; golden parachute - великі виплати керівникам у зв'язку з ліквідацією їхньої посади через погли- 
нання їхньої компанії іншою компанією [7]; balloon payment - погашення кредиту один раз повною сумою [9]; fill or kill order - замовлення на купівлю-продаж, яке автоматично анулюється, якщо не здійснене в певний період часу [9]; company doctor - консультант, радник фірми, що опинився у скрутному фінансовому становищі [8]; a sleeping partner - компаньйон, який офіщійно представляє фірму, але активно не бере участі у веденні справ [8]. Саме описовий переклад можна вважати одним із найефективніших способів передачі безеквівалентної фразеологічної лексики. Окрім того, даний спосіб перекладу використовується для уточнення, а також для цілісного розуміння певного тексту. Форма описового перекладу може бути різна, а саме пояснення, порівняння, власне звичайний опис, тлумачення. Тобто перекладач може використати будь-який спосіб для того, щоб у максимально лаконічній та водночас зрозумілій формі передати значення фразеологічної одиниці. Іноді описовий переклад є надто громіздким, що і $€$ його суттєвим недоліком.

Переклад за допомогою фразеологічного аналога посідає друге місце за регулярністю використання. Даним способом послуговуються не так часто, як описовим перекладом. Усе ж немала кількість економічних фразеологічних одиниць вибірки, а саме 59 (17,4\%) фразеологізмів, були перекладені за допомогою фразеологічного аналога. Даний спосіб перекладу вважається доцільним у тому разі, коли в мові перекладу $є$ відповідник для тієї фразеологічної одиниці, яка вживається в мові оригіналу. Особливістю такого способу перекладу є те, що образ, на якому базується фразеологізм у мові оригіналу, відрізняється від того образу, на якому будується дана фразеологічна одиниця 3 аналогічним значенням у мові перекладу. Окрім відмінності в образності, можуть траплятися і зміни в синтаксичній будові фразеологізму. Отже, переклад за допомогою фразеологічного аналога може бути вираженим більш стисло, або ж навпаки - більш розлого. Т.П. Задко зауважила, що через деякі відмінності в культурі, світосприйнятті, менталітеті та власне способі життя основна зміна під час перекладу за допомогою фразеологічного аналога полягає зазвичай у зміні образності, інколи в заміні деяких національно забарвлених компонентів [10, с. 121]. Приклади використання фразеологічного аналога під час перекладу фразеологічних одиниць економічної термінології такі: sterling work - служити вірою і правдою [11]; black economy - «тіньова економіка» [7]; cash cow - курка, яка несе золоті яйия [8]; to make money hand over fist-загрібати гроші лопатою [11]; to break the bank - «зірвати куш» [11]; to buy a pig in a poke - купити кота в мішку [9]; act of god-форс-мажор [9]. Недо- ліком даного способу перекладу вважаємо те, що емоційно-експресивне значення фразеологічної одиниці в мові оригіналу й у мові перекладу може бути різним.

За даними дослідження, дослівний переклад або калькування $є$ практично таким ж регулярним, як і переклад за допомогою фразеологічного аналога. Таким способом було перекладено 37 фразеологічних одиниць, які становлять $10,9 \%$ усієї вибірки. Якщо переклад за допомогою фразеологічного аналога належить до фразеологічного способу перекладу, то дослівний переклад, або калькування, - до нефразеологічного способу. М. Нагорна наголошує на тому, що попри невисоку якість перекладу, даний спосіб $є$ надзвичайно доцільним у тому разі, коли необхідно зберегти національну специфіку фразеологічної одиниці. Також дослідниця зауважує, що інколи такий спосіб перекладу використовується для того, щоб читач мав можливість відчути всю особливість іноземної культури [12, с. 48]. Очевидним $є$ той факт, що калькування особливо актуальне в разі перекладу безеквівалентної фразеологічної одиниці. Дослідниця Т.В. Новікова поділяе дану думку і наголошує на тому, що саме за допомогою калькування перекладачеві вдається передати безеквівалентний фразеологізм, зберегти його оригінальний образ [13, с. 206]. Недоліком дослівного перекладу $є$ те, що інколи значення фразеологізму може бути некоректно відтворене. У такому разі фразеологічна одиниця буде звучати злегка неприродно стосовно структурних та граматичних норм мови перекладу та може втратити свою образність. Використання дослівного перекладу засвідчують такі приклади: friction-free capitalism - «капіталізм без тертя» (тобто капіталізм без посередницьких організаиій) [8]; dead cat bounce - «стрибок мертвої кішки» - тимчасовий підйом на фондовій біржі після значного падіння цін, який загалом не впливає на загальну негативну тендениію [8]; Lady Macbeth strategy«стратегія леді Макбет» (стратегія, що використовується для поглинання однією компанією декількох інших, значно менших компаній) [8]; poison pill - «отруйна пігулка» (параграф статуту корпорації, щзо дає право в разі поглинання iï ворожою компанією прийняти зобов'язання, які роблять июю операцію надмірно дорогою) [8]; a bull market - «ринок биків» (ринок, який характеризується тенденцією постійного зростання цін) [7]. Приклади засвідчують, що суто дослівного перекладу тієї чи іншої економічної фразеологічної одиниці не досить для розуміння іiї суті, тому переклад супроводжується додатковим поясненням, яке здебільшого $є$ досить громіздким. Доцільність пояснення трактується тим, що його використання вносить ясність та дає можливість 
читачеві зрозуміти цілісне та реальне значення фразеологізму, а не робити власні припущення.

У процесі дослідження фіксуємо також приклади перекладу за допомогою еквівалента, суть якого полягає в тому, щоб замінити одну фразеологічну одиницю іншою. Проте така заміна однієї фразеологічної одиниці іншою можлива за умови, що значення, лексичний склад, граматична структура, а головне, образність та стилістичне забарвлення фразеологізму в мові оригіналу та фразеологізму в мові перекладу будуть збігатися. Такі абсолютні збіги фіксуємо досить рідко: black market - чорний ринок [7]; to have one's fingers in the till- «запустити руку в касу» [11]; to sell like hot cakes - розлітатися, як гарячі пиріжки [11].

Найменш регулярним способом перекладу фразеологічних одиниць економічної галузі $\epsilon$ транслітерація 3 додатковим поясненням. Для перекладу власне фразеологізмів транслітерація 3 додатковим поясненням використовується вкрай рідко: freehold - фрігольд (безумовне право власності на нерухомість) [9]; Zombie - зомбі (компанія, щзо продовжує свою діяльність, незважаючи на те, щзо вона близька до банкрутства) [9].

Висновки та перспективи подальших досліджень. Отже, проведене дослідження засвідчує, що описовий переклад $\epsilon$ найрегулярнішим способом відтворення фразеологічних одиниць економічної галузі. Хоча даний спосіб перекладу найточніше передає суть термінологічного фразеологізму, однак він позбавляє перекладений фразеологізм образності та $є$ надто громіздким, що становить труднощі для використання його під час перекладу текстів. Переклад за допомогою фразеологічного аналога та дослівний переклад використовуються значно рідше. Здебільшого дослівний переклад супроводжується додатковим поясненням, яке допомагає читачеві зрозуміти зміст іншомовного фразеологізму, однак позбавляє фразеологізм лаконічності та вирізняється громіздкістю. Украй рідко для передачі фразеологічних одиниць фіксуємо використання перекладу за допомогою фразеологічного еквівалента або транслітерації з додатковим поясненням. Перспективи подальших досліджень вбачаються у вивченні способів перекладу фразеологічних одиниць інших галузевих термінологій.

\section{ЛIТЕРАТУРА}

1. Baker M. In other words: A coursebook on translation. London and NewYork : Routledge, 2011.332 p.

2. Корунець I.B. Теорія і практика перекладу (аспектний переклад). Вінниця : Нова книга, 2003. 448 c.

3. Комиссаров В.Н. Современное переводоведение. Москва : ЭТС, 2001. 424 с.
4. Влахов С.И. Непереводимое в переводе. Москва : Международные отношения, 1980. $342 \mathrm{c}$.

5. Личук М.І., Шинкарук В.Д. Ступені фразеологізації речень. Чернівці : Рута, 2001. 135 с.

6. Доля А.В., Пільгуй Н.М. Особливості перекладу бізнес-ідіом в англомовному економічному дискурсі. Вісник Національного технічного університету «Харківський політехнічний інститут». 2015. № 13. С.63-66.

7. Collin P.H. Dictionary of Economics. London : A \& C Black, 2003. 224 p. URL: https:// saidnazulfiqar.files.wordpress.com/2013/09/dictionary-of-economics-2.pdf (дата звернення: 20.10.2020).

8. Oxford dictionary of Business and Management / Edited by Jonathan Law. 5 ed. Oxford : Oxford University Press, 2009. 600 p.

9. Кравченко Н.В. Великий англо-український, українсько-англійський бізнес-словник. Харків : Торсінг Плюс, 2009. 496 с.

10. Задко Т.П. Збереження стилістичних функцій фразеологізмів під час їх перекладу українською мовою. Науковий вісник Дрогобицького державного педагогічного університету імені I. Франка. 2016. Т. 1. № 5. С. 120-123.

11. Whitmell C. 505 Business Idioms and Phrasal Verbs. Kindle edition, 2015. 110 p. URL: https:// docuri.com/download/505-business-english-idioms-and-phrasal-clare-whitmell_59c1ced7f581710b28639707_pdf (дата звернення: 08.11.2020).

12. Нагорна М. Основні шляхи перекладу фразеологізмів українською мовою. Наука. Освіта. Молодь. 2016. № 2. С. 47-48.

13. Новікова Т.В. Переклад фразеологізмів крізь призму теоретичних досліджень. Наукові записки національного університету «Острозька академія». 2015. № 52. С. 203-207.

\section{REFERENCES}

1. Baker M. (2011). In other words: A coursebook on translation. London and New York : Routledge.

2. Korunets, I. (2003). Teoriia i praktyka perekladu (aspektnyi pereklad) [Theory and practice of translation (aspect translation)]. Vinnitsa : Nova Knyha (in Ukrainian).

3. Komissarov, V. (2001). Sovremennoe perevodovedenie [Modern translation studies]. Moskva : ETS (in Russian).

4. Vlahov, S. (1980). Neperevodimoe $v$ perevode [Untranslatable in translation]. Moskva : Mezhdunarodnyie otnosheniya (in Russian).

5. Lychuk, M.I., \& Shynkaruk, V.D. (2001). Stupeni frazeolohizatsii rechen [Degrees of phraseologization of sentences]. Chernivtsi : Ruta (in Ukrainian). 
6. Dolia, A.V. \& Pilhui, N.M. (2015). Osoblyvosti perekladu biznes-idiom $\mathrm{V}$ anhlomovnomu ekonomichnomu dyskursi [Peculiarities of business idiom translation in English economic excursion]. Bulletin of NTU “KhPI", № 13, pp. 63-66 (in Ukrainian).

7. Collin, P.H. (2003). Dictionary of Economics. London : A \& C Black. Retrieved from https:// saidnazulfiqar.files.wordpress.com/2013/09/ dictionary-of-economics-2.pdf (accessed 20 October 2020).

8. Law, J. (Ed.) (2009). Oxford dictionary of Business and Management. Oxford : Oxford University Press.

9. Kravchenko, N.V. (2009). Velykyi anhloukrainskyi, ukrainsko-anhliiskyi biznes-slovnyk [The Great English-Ukrainian/Ukrainian-English Business Dictionary]. Kharkiv : Torsinh Plius (in English \& Ukrainian).

10. Zadko, T.P. (2016). Zberezhennia stylistychnykh funktsii frazeolohizmiv pid chas yikh perekladu ukrainskoiu movoiu [Preservation of stylistic functions of phraseologisms during their translation into Ukrainian]. Scientific Journal of Drohobych Ivan Franko State Pedagogical University, vol. 1, № 5, pp. 120-123 (in Ukrainian).

11. Whitmell, C. (2015). 505 Business Idioms and Phrasal Verbs. Kindle edition. Retrieved from https://docuri.com/download/505-businessenglish-idioms-and-phrasal-clare-whitmell 59c1ced7f581710b28639707_pdf (accessed 8 November 2020).

12. Nahorna, M. (2016). Osnovni shliakhy perekladu frazeolohizmiv ukrainskoiu movoiu [The main ways of translation phraseologisms into Ukrainian]. Science. Education. Youth, № 2, pp. 47-48 (in Ukrainian).

13. Novikova, N.V. (2015). Pereklad frazeolohizmiv kriz pryzmu teoretychnykh doslidzhen [Translation of phraseologisms through the prism of theoretical research]. Scientific notes of the National University “Ostroh Academy”, № 52, pp. 203-207 (in Ukrainian). 